\title{
Research on Management of Auxiliary Fees in Residential Areas
}

\author{
Liu Zhigong ${ }^{1}$, * Wang Linjing ${ }^{1}$ \\ ${ }^{1}$ State Grid Rizhao Power Supply Company, Rizhao, Shandong, China, 276826 \\ *Corresponding Author: Liu Zhigong
}

\begin{abstract}
Keywords: Residential Areas, Auxiliary Fees, Management Situation and Countermeasures
\end{abstract}
\begin{abstract}
The process of residential areas construction has been accelerated in recent years. The problem of how to optimize and improve the management of auxiliary fee in residential areas, especially the construction fees, maintenance fees and management fees of facilities of power distribution and power supply, has been the common concern of house owners, power supply enterprise and property administrative department. Therefore, this paper analyzes the current situation of management of auxiliary fees in residential areas. Combined withthe construction fees standards of newly-built residential areas issued by the price controldepartmentsin different cities in Shandong, this paper discusses achievements and the existing problems of the management of auxiliary fees in residential areas and puts forward the rational strategies to improve the work efficiency of auxiliary fees management in order to provide reference for the management of auxiliary fees in residential areas in China.
\end{abstract}

\section{Introduction}

In order to improve the safe operation level of thedistribution network in the local residential areas and the quality and reliability of power supply for the residential district, this paper collects and collates the data of the management of auxiliary fees on the basis of the author's own experience. According to the new requirements of the residential district matching fees in our city, it analyzes the advantages and disadvantages of the unified standard, unified fees, unified planning and unified management of the power auxiliary project in residential areas.At the same time, this paper gives some rational suggestions on the fees management of residential facilities in our city and enriches the content of the theory of residents residential facilities fee management to lay the theoretical basis for the realization of the high quality, high efficiency of residential facilities fees management work.

\section{Current Situation of Management of Auxiliary Fees in Residential Areas}

The characteristics of the present situation of the matching fee management in residential areascan be summarized as the following five points:

First, the national related departments have strengthenedthe supervision and the policy guidance of on management of auxiliary fees in residential areas. A series of treaties and plans for the management of the auxiliary fees have issued to the provinces and autonomous regions government, improving the corresponding fees collection policy. Second, the functions of the matching fee executive department have been perfected, forming an integrated management systemwhich has a clear division. It greatly improves the efficiency of matching fee management in residential areas. Third, great importance has been attached to the management of auxiliary fees in residential areas by the local related departments. According to the actual situation of the regions and the advices of 
house owners, power supply enterprise and property administrative department, all government departments promulgated and improved fees management schemes in residential areas.Fourth, the management of the auxiliary fees in residential areas has been interfered by different problems in the actual implementation process. As the problem brought by the management fees standard is prominent, the management work of the auxiliary fees in residential areas has been influenced to some degree. Fifth, in residential areas supporting fee management and research staff capacity has been greatly improved, especially in residential areas of auxiliary fees management research, more attention to auxiliary fees management actual implementation and rationality, supplemented by related management personnel to ensure the normal development of residential areas supporting the management fee.The management and research ability of the staff has been greatly improved. They pay more attention to the practical implementation and rationality in the auxiliary fee management in the residential areas. The addition of related management personnel ensures the normal work of management of auxiliary fees in residential areas.

\section{Advantages and Disadvantages of Management of Auxiliary Fees in Residential Areas}

Since the abolition of the national power supply subsidy policy, the price control departments of all cities in Shandong province have successively promulgated new engineering construction fee standards of supply and distribution facilities in residential areas. The new residential supply and distribution facilities have been implemented the unified standard, unified fees, unified planning and unified management. The distribution facilities construction fees of residential areas have been charged as a uniform fare by the Rizhaopower company. The forms are centralized management, reasonable arrangement, special storage and particularpurpose. We no longer charge others for power distribution project cost (temporary construction power except). At the same time, the power supply company formulates the distribution plan, implementation schedule to ensure residential supporting power supplyin accordance with the relevant provisions of the power net.

The introduction of the matching fee collection policies in residential areas solved the problems and disputes in the operation and management process led by the unclear division of property right. It effectively enhanced the work quality and efficiency of the management of auxiliary fees in residential areas. In terms of the property division, the residential areas implemented the policy of unified management. It did not need the function division and negotiation cost of the house owners, power supply enterprise and property administrative department, avoiding the disputes and contradictions.In addition, the function division of the management of residential district matching fee is clearer and the management process is more reasonable. These reforms are more likely to be accepted by the house owners, power supply enterprise and property administrative department.

Due to the regional characteristics of the matching fees management standards and the high attention of the society, a series of problems have occurred in the actual implementation. It brought about some negative impacts to the matching fee management work in residential areas. For example, the regulations of the matching fee standards require the one-time paymentin the construction of residential power supply. However, this programjust takes the expenditure of new power supply facilities, ignoring the expenditure of the daily maintenance and failure repair after the completion, which gives great burden to the power supply enterprise; in addition, the user's assets are maintained by the power supply enterprises. The enterprisetakes great electrical safety risk and compensation liability.Therefore, in summary, the introduction and implementation of the matching fee management standards in residential areas brings a great test to the development of power supply enterprises. It needs fully consideration in the future. 
Reasonable Measures of Improving Efficiency of Management of Auxiliary Fees in Residential Areas

Strengthening the Policy Guidance of National Related Department on Management of Auxiliary Fees in Residential Areas. In terms of the auxiliary fees management in residential areas, the Chinese government relevant departments should continue to carry out the policy guidance and urge the regional administrative department to supervise the residential facilities fee management to ensure the implementation of the relevant policies. Therefore, from the perspective of the policy implementation, the improvement of the efficiency of the management of residential areas feescannot be separated from the strong policy guidance. Local governments should correctly execute therelevant policies of our country in the management work of the auxiliary fees in residential areasto promote the reform process of auxiliary fee management to accelerate.

Perfecting Work System and Related Content of Management of Auxiliary Fees in Residential Areas. In terms of the work system and related content of management of auxiliary fees in residential areas, we should summarize related work experience, learn the new management idea and management mode and further improve the work system and content of the matching fee management to enhance the efficiency of management work. Moreover, the improvement of the management model ofthe matching fee in residential areasshould be improved from the aspects of management mode, management ideas, management personnel and others to realize the comprehensive progress of the auxiliary fees in residential areas.

Promoting Management Capabilities of Managers of Auxiliary Fees in Residential Areas. From the perspective of the professional level of the managers of auxiliary fees in residential areas, certain differences exist in different areas in China. Part of thepractitioners need to enhance their ability of management.Therefore, to enhance the management ability of the practitioners is also the important means to improve the management efficiency of auxiliary fees in residential areas. This idea should keep for a long time. We should adhere to the professional abilitycultivation and promotion in the field of the auxiliary fees management in residential areasin the future.

Intensifying Research Degree and Practice Test of Management of Auxiliary Fees in Residential Areas. The theoretical research and practical test of the management of the matching fee are also important factorsof the efficiency of the management of the matching fees. So it is necessary to increase the research efforts on the management of the auxiliary fees. And then, we improve the matching fees management approachthrough a reasonable pilot test to enhance the management efficiency. Therefore, it should be targeted to the culture research talent in this area. The formation of specialized research team of the auxiliary fees management should also be built. The research team can combine the local actual situation and regulate the standards of matching fees to realize the progressof the management work.

\section{Conclusion}

With the accelerating pace of the construction of the new residential areas in China, the management work of the auxiliary fees in residential areas has been more and more important. To further enhance the efficiency of management, we must strengthenthe policy guidance of national related department on management of auxiliary fees in residential areas, perfect work system and related content of management of auxiliary fees in residential areas, promote management capabilities of managers of auxiliary fees in residential areas and intensify research degree and practice test of management of auxiliary fees in residential areas. These measures can contribute to the comprehensive progress of the matching fees management in residential areas. 


\section{References}

[1] Cao Jie, Optimal Design and Management Research on Power Supplies Solution of Matching Electric Power Building of New Residential Quarters, D., Hefei University of Technology, 2007.

[2] Liu Zhao, Huang Yikun, Problems and Countermeasures of Supporting FacilitiesConstruction of Newly Built Residential Areas-Taking the Complaints and Appeals of Residents in Shenyang as the Data Source, J., Journal of Shenyang Jianzhu University (Social Science), 2013, 15(2): 174-179. 